\title{
RNF43 Gene
}

National Cancer Institute

\section{Source}

National Cancer Institute. RNF43 Gene. NCI Thesaurus. Code C107649.

This gene is involved in both protein ubiquitination and the Wnt signaling pathway. 